\title{
NATIONALISM IN A NEW SYRIA ${ }^{1}$ ANTOUN SAADEH AND THE LATIN-AMERICAN MAHJAR

\author{
NACIONALISMO EM UMA NOVA SÍRIA \\ ANTOUN SAADEH E O MAHJAR LATINO-AMERICANO
}

Diogo Bercito ${ }^{2}$

\begin{abstract}
Resumo: Este artigo investiga o papel do mahjar no desenvolvimento do nacionalismo árabe, com uma atenção especial à experiência de Antoun Saadeh na América Latina. Como outros diversos ideólogos do nacionalismo árabe, ele desenvolveu sua noção de "nação" durante os anos que passou no exterior. Suas ideias estavam presentes em Suriya alJadida, um jornal que publicou no Brasil de 1939 a 1941. Analiso três textos daquela publicação para entender como ele abordou a diáspora latinoamericana e que papel esperou dela. Com isso, coloco ênfase na importância do mahjar para o pensamento político de países de idioma árabe.
\end{abstract}

Palavras-chave: Antoun Saadeh; mahjar; nacionalismo; Brasil.

\begin{abstract}
This article investigates the role of the mahjar on the development of Arab nationalism, with a particular interest in Antoun Saadeh's experience in Latin America. Like many other Arab nationalism ideologues, he developed his conception of the "nation" during the years he spent abroad. His ideas were present in Suriya alJadida, a newspaper he published in Brazil from 1939 to 1941. I analyze three articles from that publication in order to understand how he reached out to the diaspora in Latin America and the role he expected it to play. With that, I emphasize the importance of the mahjar to the political thought of Arabic-speaking countries.
\end{abstract}

Keywords: Antoun Saadeh; mahjar; nationalism; Brazil.

\section{Introduction}

When Brazilian Education minister Fernando Haddad visited Lebanon in 2006, he traveled to the remote and drowsy village of Ain Ata to inaugurate its public library. It was like coming home. His father Khalil al-Haddad had left the same village in 1947 and migrated to Brazil. So had his grandfather Habib al-Haddad, for whom the new building was named. During the ceremony, the minister donated some of the books he had inherited from relatives in São Paulo, including works by Antoun Saadeh.

This may have been a small episode with little political importance. Nevertheless, it reminds us that migration is not a unidirectional arrow pointing from one original country to a new one. Rather, it involves complex comings and goings and the exchange of ideas.

\footnotetext{
${ }^{1}$ Kevin Martin and Tariq Adely contributed with comments. Without them, I would not have written this article.

2 The author is a Brazilian journalist and scholar. He worked with Folha de S.Paulo as a foreign correspondent in the Middle East. He holds an MA in Contemporary Arab and Islamic Studies from Universidad Autónoma de Madrid. This essay was written during his MA in Arab Studies at Georgetown University. ORCID ID: https:// orcid.org/0000-0001-8373-7160. Link para a Plataforma Lattes: http://lattes.cnpq.br/6247071137720148. Contato: diogo.bercito@gmail.com.
} 
One of these interchanges is embodied by the telling presence of Saadeh's books on the Haddad family bookshelves and the return of these volumes to Lebanon. Saadeh had lived in Brazil from 1920 to 1930 and once again from 1938 to 1939, and his particular ideas about the "nation" were developed during his experience in the mahjar, or Arab diaspora.

This essay will investigate the importance of the mahjar in Saadeh's thought and describe his interaction with that diasporic community. My primary source is the newspaper Suriya al-Jadida (New Syria), published in Arabic in São Paulo for two years (1939 - 1941). With this work, I seek to contribute to a relatively recent trend in the study of Arab history, which analyzes the impact of the departure from and return to Lebanon of tens of thousands of Arabs between 1870 and 1930. Therefore, my study will hopefully contribute to filling the lacuna Akram Fouad Khater cited in his book Inventing Home:

\begin{abstract}
The idea of the "nation" as developed in the mahjar is a research subject that is very much in need of being pursued. Studies of Arab nationalism which focus solely on events and ideological currents in Syria, Lebanon, and the Ottoman Empire provide only a part of the picture because many of the nationalist debates took place in Brazil, Argentina, and the United States. There, the emigrant community was confronted with an identity connected to the mythical structure of the nation, a kind of identity they had not encountered before. This encounter obliged some of them to start defining a countervailing national identity. For example, Antoun Saadeh lived in Brazil for a prolonged period. There he began to formulate his thoughts on "Greater Syria" (Khater, 2001: 195-196).
\end{abstract}

Other nationalists, including Pierre Gemayel, Zaki al-Arsuzi, Michel Aflaq, and Salah al-Din al-Bitar spent long periods of time abroad. In places like Egypt, France, the United States, Argentina, and Brazil, they were exposed to the nationalist ideas articulated in those host countries, questioned their previous definitions of the nation, and took advantage of levels of freedom of speech they had not experienced in the Ottoman Empire before their migration (Schumann, 2004: 600).

\title{
Historical context
}

Arab migration to the Americas began in the last decades of the 19th century. When they left the Ottoman Empire, migrants were classified as Ottomans, Turks, Turk-Asians, and Syrians, though they had been born in places that would later become new, "invented" states like Turkey, Syria, Lebanon, and Palestine.

Scholars estimate that more than 300,000 people left the Middle East between 1870 and 1930 (Karam, 2007: 10), most of them going from what is now Lebanon to South America. Brazil received 140,000 Arabic-speaking migrants between 1880 and 1969, among whom were the parents of Fernando Haddad and of other prominent political figures. The Brazilian and Lebanese governments estimate that Brazil hosts between 7 and 10 million Lebanese citizens and their descendants, although this number is highly contested. ${ }^{3}$

${ }^{3}$ Statistics vary due to archival limitations and, in this scenario, there are several competing estimates. The 
This exodus, by which Lebanon lost one-fourth of its population between 1900 and 1914 (Rogan, 2009; 212), was caused by several factors. Many of these migrants cited religious persecution as one of the main reasons why they left their country. Recent studies, however, have portrayed that explanation as a sort of a myth forged by the diaspora and their offspring, who had a particular interest in portraying their emigration as a desperate flight for survival (Naff, 1985). Economic hardships are a less-contested factor: overpopulation, a decrease in the price of silk after the invention of rayon, and a phylloxera epidemic affecting grape plantations led people to seek better prospects across the ocean (Knowlton, 1955: 38). They had heard that America was a land of opportunities, an idea circulated by the local press, by letters from relatives, and by Brazilian Emperor Dom Pedro II, who visited Beirut in 1876 and expressed a wish that Arabs would migrate to his country. ${ }^{4}$

The mass migration happened during the same period as the appearance of nationalism in Arab countries such as present-day Syria and Lebanon. Nationalism, as defined by Peter Wien, is a "reference system for the shaping of collective identities" (Wien, 2017: 1) that "creates belonging" (Wien, 2017: 2). He cautions us, however, against reductionism, for "there is a conglomerate of sometimes contradictory, sometimes complementary Arab nationalisms that take different forms in the different Arab lands and are deeply rooted in local delineated Arabness" (Wien, 2017: 3). Not all Arab nationalists agreed, for example, on the meaning of being an Arab. There was also a fiery dispute on what is the common factor uniting Arabs - language, history, culture, religion, or territory.

According to Eugene Rogan, "the idea of the nation as a political unit - a community based in a specific territory with the aspiration of self-governance - was the product of European Enlightenment thought that took root in the Middle East." It benefited from the nahda (literary renaissance), the expansion of book circulation, and the proliferation of newspapers, which "planted the seed of an idea that would prove hugely influential in Arab politics: that the Arabs were a nation, defined by a common language, culture, and history" (Rogan, 2009: 138-139).

Arabic-language publications in the diaspora were central to creating a common identity. Newspapers and magazines in the mahjar, including Suriya al-Jadida, played a crucial role in "maintaining [the bonds] with the former home countries and creating a shared identity as a diaspora," shaping what Christoph Schumann defines as an "Arabic trans-regional public sphere" (Schumann, 2004: 601). Debates around the meaning of being an Arab, Schumann argues, happened across many countries.

governments of Brazil and Lebanon do not offer any explanation for their numbers, and the source might be the mahjar itself. Most scholars estimate that there are around 3 million Lebanese and their descendants in Brazil.

${ }^{4}$ Historians disagree on whether the emperor's invitation actually led Arabs to migrate to Brazil, but some migrants did cite his direct influence. See, for instance, the stories collected in DUON, Taufik. A Emigração Sírio-Libanesa às Terras de Promissão. São Paulo: Tipografia Editora Árabe, 1944, p. 86-87. 
By the turn of the century, nationalist intellectuals were trying to formulate definitions of the Arab nation. Marginalized in their countries of origin, they left for the mahjar, where they exchanged ideas with foreign nationalists. The different nationalisms that emerged during those decades reflected the contributions of their various proponents. Jurji Zaydan, for instance, suggested that the Arabs should educate themselves and only then seek administrative independence from the empire (Phillipp, 1979: 209-210). Michel Aflaq, a Syrian Christian who helped to shape the Baathist movement, used Islamic and Christian images in his speeches, causing some to see his Arab nationalism as a form of faith (Wien, 2017: 12). In the middle of the 20th century, Gamal Abdel Nasser created a nationalist socialism in Egypt (Rogan, 2009: 277).

The concurrent development of different conceptions of the nation - Arab, Islamic, or tied to a specific land - was paramount to this process. Antoun Saadeh, described in more detail in the following section, proposed a nation defined mainly by territory, a concept that helped him putting forward his theory of a "Geographic Syria" that included present-day Syria, Lebanon, Israel, Palestine, Jordan, Iraq, and parts of Turkey. Saadeh defined geography as "the determining factor for the constitution of nations and therefore also the main criterion for their distinction from each other" (Schumann, 2004: 604-605). It is in this context that we should read the concept of "Syrian migrant," an expansive term that refers to the diaspora in South America constituted by what scholars now call Syrians, Lebanese, and Palestinians.

\section{Saadeh and his new Syria}

Although the majority of the articles in Suriya al-Jadida were unsigned, the voice of its publisher is ever present within its pages. Several of the pieces mention Antoun Saadeh — frequently referred to as "al-zaīm" (the leader) — and use his name to legitimize the publication's nationalistic message.

Antoun Saadeh (1904 - 1949) was born in Dhour El Choueir, a town in present-day Lebanon. His father, the nationalist intellectual Khalil Saadeh, fled the Ottoman Empire, residing in Egypt from 1901 to 1913, in Argentina during World War I, and finally moving to Brazil in 1919 in response to an invitation from the local Syrian community. According to Nawwaf Hardan in Sa'ada fi al-Mahjar, the Syrian diaspora in Brazil insisted that he lived there in light of his leading role in the renaissance and his pioneering journalism (Hardān, 1989: 31).

Saadeh joined his father in 1921. Hardan tells us that soon after Saadeh's arrival he started going to a Syrian school in São Paulo, where he studied Arabic, Portuguese, and English. His first school is unfortunately not named (Hardān, 1989: 32), but it seems that in 1928 Antoun enrolled in the Ginásio Oriental (Oriental High School), founded by Wadih Yázigi in São Paulo (Hardān, 1989: 196).

At the same time, Saadeh and his father worked together editing the publications 
al-Jarida (The Newspaper) and al-Majalla (The Magazine). Their office was located in the 25 de Março Street, in downtown São Paulo, where most Syrian-Lebanese lived.

Saadeh joined a Masonic lodge in São Paulo and, as he gained prominence among his peers, he started to form a series of small organizations in the diaspora, such the clandestine Syrian Heroic Youth Association (Jama'iya al-Shabiba al-Fidā'iya al-Suriyya). Founded in 1925, the association at first gathered six members of the Syrian community. Hardan names five of the six members: Henri Daou, Abdo Jazra, Rashid Maluf, Felipi Lutfala, and Ragi Abu Jamra, while the remaining member is left unnamed ${ }^{5}$.

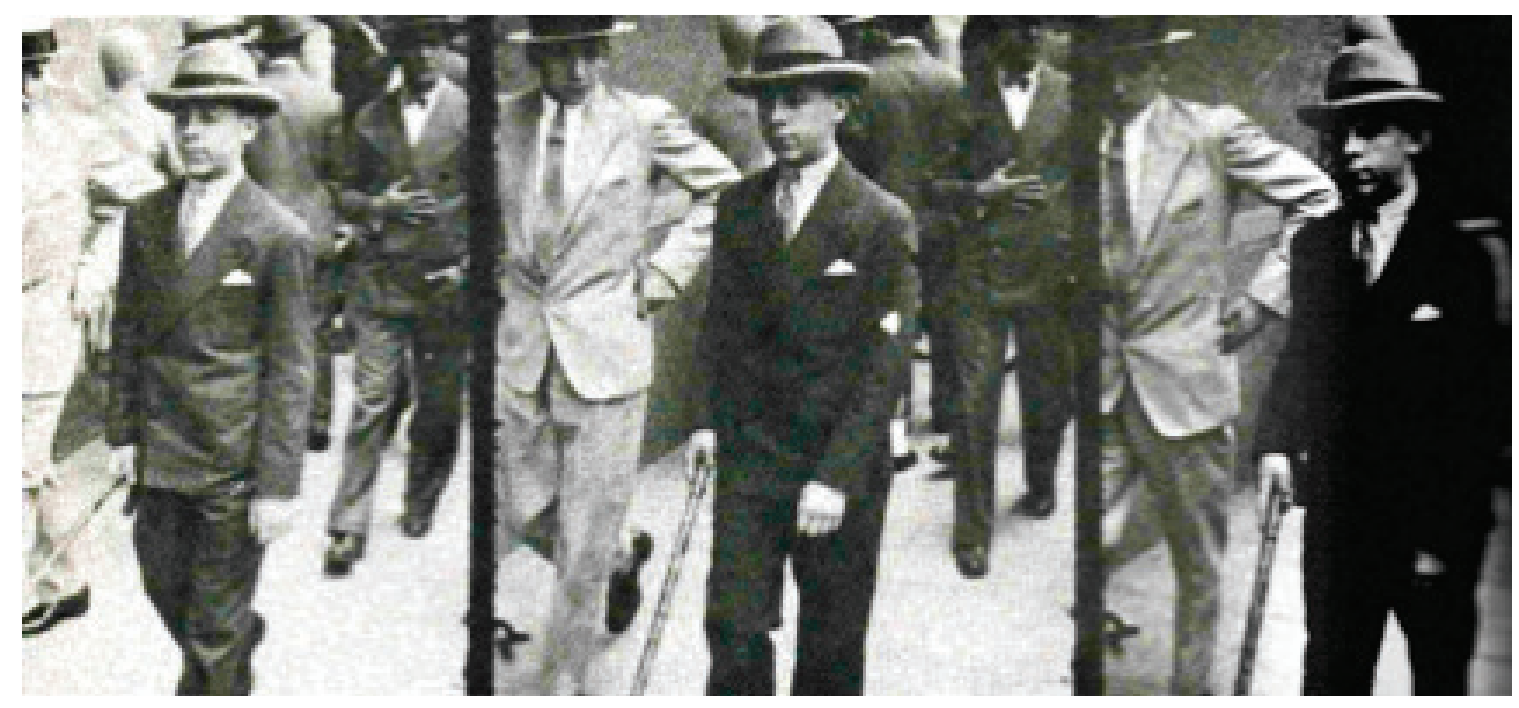

Antoun Saadeh in São Paulo between 1922 and 1923. HOURANI, Albert (ed.). The Lebanese in the World: a Century of Emigration. London: Centre for Lebanese Studies, 1992. Plate 30

The association's stated goal was to gather Syrian nationalists and promote their views through their writings in al-Majalla. However, part of the membership was unhappy with the decision to remain clandestine - in particular after witnessing revolts in their home country against the French mandate. In response to these disagreements, Saadeh left the group the same year of its creation. That same year, he began a new project: the Party of the Free Syrians (Hizb al-Ahrar al-Suriyyina) (Hardān, 1989: 31).

That party was also clandestine, according to Hardan, and advocated for the independence of Syria inside its "known geographical borders." Hardan provides a letter sent by the French ambassador in Brazil to the French minister of Foreign Affairs informing him about Syrian nationalists in Brazil, naming Saadeh among them (Hardān, 1989: 147). That document thus provides a compelling indication of how closely the French authorities were following Syrian nationalism in the diaspora, including in Brazil.

Hoping to extend his political work to his own homeland and to fight for its

\footnotetext{
${ }^{5}$ Instead of transliterating the names from Hardan's book in Arabic, I located these same migrants in Hajjar's list of Arab intellectuals in Brazil and adopted the Portuguese version of their names. See HAJJAR, Claude F. Imigração Árabe: 100 Anos de Reflexão. São Paulo: Ícone Editora, 1985, p. 181.
} 


\section{artigo}

independence, Saadeh went back to Beirut in 1930. Only two years later, he launched what became his most renowned political project, the SSNP (Syrian Social Nationalist Party). Persecuted by the French Mandate authorities, he returned to Brazil in 1938, where he remained for a brief period before heading to Argentina for nearly a decade (Schumann, 2004: 602).

During this second period abroad, Saadeh founded Suriya al-Jadida in São Paulo, a very different publication from those he had edited with his father.

While Khalil understood the press as a space for the pluralistic exchange of ideas, Saadeh saw it as a tool for "spreading the party doctrine among the Syrians in the diaspora [...], to work for the transformation of society according to one specific worldview, namely the one laid out in the party doctrine" (Schumann, 2004: 608).

Saadeh published the first issue of Suriya al-Jadida on March 11, 1939. This weekly newspaper, described by Christoph Schumann as the SSNP's "pure party press" (Schumann, 2004: 608), survived until at least 1941.6 It was usually eight pages in length and entirely in Arabic, except for a Portuguese version of the title, Diário Syrio (Syrian Diary), appearing on the final page. The intended readership, as stated throughout the newspaper's copy, was the "Syrian" diaspora.

Saadeh returned to Beirut in 1947. Once settled in that city, he was again persecuted by Lebanese officials and fled to Damascus. There, he was arrested, handed over to the Lebanese authorities, and executed in Beirut in 1949 (Schumann, 2004: 603).

\section{Textual analysis}

The centrality of the diaspora to Saadeh's nationalist project and his efforts to reach members of this community are foregrounded in the pages of the whole history of Suriya al-Jadida. My investigation aims to provide in-depth analysis of a few selected texts, which I argue are representative of a larger corpus of journalistic work. I chose three early pieces that feature explicit statements of its editor's expectations of the mahjar. I begin with the front page story of the newspaper's first ever issue. I move to a letter to "readers" appearing in the same edition. Finally, I analyze an article entitled "What Does the Leader Want?" appearing in the following week's issue.

The headline of the first article, published on March 11,1939, repeats the newspaper's title in large letters. It also explains its meaning: in the context of a "nationalistic renaissance" ("nahda qawmiya"), a new Syria was emerging. "And the New Syria is not merely a new name, but a sign of a new life."7

The word "new" appears in several passages of the article. For example, it is present in the claims that "Syria has a new soul" ("rūh jadīda") and that "new blood runs in its veins" ("tajrī fì 'urūqihā damā' jadīda"). The author says that the Syrians had high expectations,

6 The latest issue available in the archives of the American University of Beirut.

7 Sūriya al-Jadīda, "sūriya al-jadīda." March 11, 1939. 
which were frustrated by earlier nationalist movements "as the coming of the Messiah disappointed the Jews."

The text discusses hundreds of Syrians' desire to see their homeland "thriving" ("muzdahiran") and reminds readers that "Saadeh advocated patriotism and morality." Mentions of Saadeh's name are frequent in other issues of the newspaper, a device that both establishes legitimacy and reinforces Saadeh's position as the leader of the whole community. The opening article also quotes the late historian Philip K. Hitti claiming that he "spoke of the naturalness of the Syrian nation and its geographical unity" ("tabī'at al-wațan al-sūrì wa-wah datihi al-jughrāfiya"). In the last lines, the author concludes by stating the newspaper's goal: "to serve the new Syria in its nationalistic renaissance.""

A short letter appeared in that same issue, entitled "ilā al-qāri"' ("To the readers"). The text is a direct message to the readership, telling them why they should read that newspaper instead of the several other Arabic-language publications available in the diaspora. "We feel, above all, that you have demands that need to be resolved." The other newspapers, it is implied, were failing in that mission. ${ }^{10}$

The letter enumerates the four main goals of the publication. In summary, they were: 1. "honesty in the news" ("al-amāna fī al-akhbār"); 2. relying on "original sources" ("maṣādirihi al-awliya"); 3. providing "independent analysis of topics such as politics, economy and society" ("al-dars al-mustaqbal li-kull mawḍū' siāsī aw iqtiṣādī aw ijtimā'ī"); 4. "choosing what is useful and rejecting what is bad" ("intiqā' al-mufīd wa-nabdh al-ḍār"). ${ }^{11}$

With these remarks, the author tried to differentiate Suriya al-Jadida from the dozens of other Arabic newspapers published in Brazil during those years. He also claimed to follow the standards of modern journalism, i.e. honesty and access to original sources. ${ }^{12}$

The last text I analyze, entitled "What Does the Leader Want? ("mādhā yurīd alza'īm?"), was published in the second issue of Suriya al-Jadida. Saadeh is only referred to as the "leader" in the headline, as though his prominence within the community was widely understood and thus unspoken. ${ }^{13}$

The author of the article begins by informing readers that he approached Saadeh and asked him "what he wants from the Syrian migrants." Saadeh replied that the only solution to the problems facing migrants was "national liberation" ("al-taharrur al-qawmī”). Saadeh then referred to a speech he delivered on December 28, $1937 .{ }^{14}$

The writer asked Saadeh if he had anything specific to ask from the Syrian community in Brazil. "That they keep good relations between the two people, Syrians and Brazilians, and respect the laws of the country where they reside." Lastly, the author tells the readers

\footnotetext{
${ }^{8}$ Ibid.

${ }^{9}$ Ibid.

${ }^{10}$ Sūriya al-Jadīda, "ila al-qāri'” March 11, 1939.

${ }^{11}$ Ibid.

${ }^{12}$ Ibid.

${ }^{13}$ Süriya al-Jadīda, "madha yurìd al-za'îm." March 18, 1939.

14 Ibid.
} 


\section{artigo}

that Saadeh wants them to "support their communities' renaissance, which wants to remove from their nation the shadow of colonialism" ("zul al-isti'amār"). ${ }^{15}$

Below the interview, the newspaper published Saadeh's 1937 speech. In order to establish a connection between him and the people in the mahjar, Saadeh talks about the years he spent in Brazil. He acknowledges that Syrian migrants heard a lot about nationalism in the diaspora, "as I also [heard it] when I was an expatriate with you." The main difference, he insists throughout the speech, is that previous nationalist movements did not address the real questions faced by Syrians, but the SSNP did. ${ }^{16}$

\section{Conclusion}

The three articles analyzed above, representative of a much larger corpus, attest to Saadeh's efforts in reaching the mahjar. He not only grew up in Latin America and developed his first ideas of the nation while living there, but he also insisted until his death that the diaspora was central to the Syrian national struggle.

Saadeh published newspapers in Brazil and Argentina, repeatedly insisting that the mahjar engage in his project of building an independent Syria encompassing the neighboring territories of present-day Lebanon, Israel, and Palestine. When he spoke with the migrants, he emphasized his own story as an expatriate and presented himself as their leader. Underscoring the significance of Saadeh's gesture towards the diaspora, Christoph Schumann concluded that "no other Syrian party has undertaken a comparable effort to bring emigrants back into the political game in Syria" (Schumann, 2004: 606). This aspect of Saadeh's mission remains understudied.

Saadeh's impact on the mahjar is visible, for instance, in the 1985 book Imigração Árabe: 100 anos de Reflexão, one of the few comprehensive works that discuss Arab migration to Brazil. The author, the Lebanese migrant Claude Fahd Hajjar, dedicates the text to the National-Social Syrian Movement, "a quem devo minha formação intelectual" ["to which I owe my ideological formation"] (Hajjar, 1985: 7). Saadeh's influence is now immortalized with a street in his name in the Brazilian city of Curitiba (Curitiba, 2014).

According to Joseph Walker Leidy's analysis of Saadeh's experience in Argentina, the mahjar played "little to no role in histories of Saadeh, many of which are hagiographical and uncritical in nature" (Leidy, 2016: 3-4). Hence, although his early years in Brazil are frequently mentioned, they are little more than a passing biographical comment.

In spite of that, Leidy insists that Saadeh witnessed during the time he spent in Brazil "the development of intellectual tendencies that would eventually provide the foundation for the various nationalist doctrines of the SSNP" (Leidy, 2016: 17). Leidy argues that Saadeh adopted historicist ideas in Brazil that praised Syrian civilization, informing his conceptualization of a "Geographical Syria." That idea "took shape in part in opposition 
to integrationist formulations of Arab history that were common in Brazil's Syrian elite circles as well as in other places throughout the mahjar," he argues (Leidy, 2016: 27). Saadeh was particularly uncomfortable with the idea that Syrian migrants might one day fully integrate the Brazilian society and remain in the mahjar, instead of returning to the Middle East and fight for their ancestral lands.

A subject for future research is which authors and books in the mahjar specifically influenced Saadeh's political thought. Schumann only briefly considers this question, assuming that Saadeh adopted the racial theories that were dominant in Brazil, such as those of Plínio Salgado's Integralist Movement. According to Schumann, the SSNP leader "came to the conclusion that it is not the pureness of race but the fusion of different races within one distinct territory that leads to cultural ascent" (Schumann, 2004: 605). That idea, very popular during his residence in Brazil, may have influenced his conceptualization of a "Geographical Syria." That is not to say that Saadeh imported or copied Salgado's ideas — instead, I would argue for the applicability of Edward Said's notion of "traveling theory," in which he describes how certain ideas travel across boundaries and adapt themselves to new environments (Said, 1983: 226-247).

There seems to be no textual evidence that Saadeh actually read Salgado. But there is one indication that Salgado's ideas at least circulated among the Arab diaspora and was seen as relevant to their context: the book Álbum da Colônia Sírio-Libanesa no Brasil [An Album of the Syrian-Lebanese Colony in Brazil].

Published in 1948 by Salomão Jorge, one year before Antoun Saadeh's death, the Álbum gathers articles from several authors who wrote about the Syrian-Lebanese diaspora in Brazil. One of the texts is penned by the Brazilian sociologist Gilberto Freyre, with the description of the Moorish influence on Brazil. The Álbum also contains a text written by Salgado during his travel to Syria.

Salgado describes "Syria," including present-day Lebanon, as a complex place made of "superposed, mixed, coexisting races, Arameans, Maronites, Druzes, Hagrites, Abbasids, Seljuks," an idea that fits Saadeh's own vision of a "Geographical Syria" which transcended religious differences. Salgado also shows his proximity with the Syrian-Lebanese community, quoting a migrant called Miguel Helou ("my close friend") and praising those Arab migrants (Jorge, 1948: 448).

It is also telling that the Álbum includes a text written by the Lebanese-American professor Philip K. Hitti about the contributions made by Arabs to the West. As John Tofik Karam shows in his article "Philip Hitti, Brazil, and the Diasporic Histories of Area Studies," Hitti visited Brazil in 1925 and 1951 and influenced the creation of an Arab Studies chair at the University of São Paulo. His first visit happened while Saadeh was living there. Regardless of them having met or not, which is not registered in documents, his passage at the very least influenced other nationalists, such as Said Abu Jamra.

In that sense, Karam quotes a letter by Hitti saying that he met with Abu Jamra. "The 
Syrians are more Syrian here than in Syria," he wrote afterwards (Karam, 2014: 451-471). Furthermore, Hitti, who is cited in Suriya al-Jadida, shared the idea that geography was determinant in shaping a Syrian people - the same concept which was propagated by Saadeh.

It remains unclear if Saadeh, Salgado, and Hitti ever met, or if they influenced each other in any direct way. But it seems at least plausible to assume that they operated in the same intellectual context, sharing a common view of what is the nation.

The possible intellectual exchange between the three is a potential avenue for further investigation. Above all, the circulation of nationalist ideas among the Arab migrants to Latin America during the first decades of the 20th Century had a profound impact - still not completely acknowledged by scholars - upon the Arab world.

\section{Bibliography}

\section{Primary sources}

Sūriya al-Jadīda, "sūriya al-jadīda." March 11, 1939.

___ "ila al-qāri'.” March 11, 1939.

, “madha yurīd al-za'îm." March 18, 1939.

\section{Secondary sources}

CURITIBA. Câmara Municipal. Lei ordinária 14.565/2014. Curitiba, 4 de dezembro de 2014.

DUON, Taufik. A Emigração Sírio-Libanesa às Terras da Promissão. São Paulo: Tipografia Editora Árabe, 1944.

HAJJAR, Claude F. Imigração Árabe: 100 Anos de Reflexão. São Paulo: Ícone Editora, 1985.

HARDĀN, Nawwāf. Sa āda fĩ al-Mahjar. Beirut: Dār fikr li-l-abhāth wa-l-nashar, 1989, p. 31.

HOURANI, Albert (ed.). The Lebanese in the World: a Century of Emigration. London: Centre for Lebanese Studies, 1992. Plate 30.

JORGE, Salomão. Álbum da Colônia Sírio-Libanesa no Brasil. São Paulo: Sociedade Impressora Brasileira, 1948.

KARAM, John T. Another Arabesque. Syrian-Lebanese Ethnicity in Neoliberal Brazil. Philadelphia: Temple University Press, 2007, p. 10.

. Philip Hitti, Brazil, and the Diasporic Histories of Area Studies. International Journal of Middle East Studies, v. 46, n. 3, 2014, p. 451-471.

KHATER, Akram F. Inventing Home: Emigration, Gender and the Middle Class in Lebanon, 1870-1920. Berkeley: University of California Press: 2001.

KNOWLTON, Clark S. Spacial and Social Mobility of the Syrians and Lebanese in the City of São Paulo, Brazil. Ph.D dissertation, Vanderbilt University, 1955. 
LEIDY, Joseph W. Antun Saadeh in the mahjar, 1938-1947. MA dissertation - The University of Texas at Austin, 2016.

LESSER, Jeffrey. Negotiating National Identity: Immigrants, Minorities and the Struggle for Ethnicity in Brazil. Durham: Duke University Press, 1999.

. (Re)Creating Ethnicity: Middle Eastern Immigration to Brazil. The Americas, v. 51, n. 1, 1996.

NAFF, Alixa. Becoming American: The Early Arab Immigrant Experience. Carbondale: South Illinois University Press, 1985.

PHILLIPP, Thomas. Ğurği Zaidān: His Life and Thought. Beirut: Orient Institut, 1979, p. 209-210.

ROGAN, Eugene. The Arabs: A History. New York: Basic Books, 2009.

SAID, Edward. Travelling Theory. In: The World, the Text, and the Critic. London: Faber and Faber, 1983, p. 226-247.

SCHUMANN, Christoph. Nationalism, diaspora and civilisational mission: the case of Syrian nationalism in Latin America between World War I and World War II. Nations and Nationalism, v. 10, n. 4, 2004.

WIEN, Peter. Arab Nationalism. The Politics of History and Culture in the Modern Middle East. New York: Routledge, 2017.

Texto recebido em: 25 de janeiro de 2019. Aprovado em: 20 de Abril de 2019. 